\title{
Identification of point mutations in exon 2 of GDF9 gene in Kermani sheep
}

\author{
R. Khodabakhshzadeh', M.R. Mohammadabadi', A.K. Esmailizadeh', \\ H. Moradi Shahrebabak², F. Bordbar', S. Ansari Namin'1
}

${ }^{1}$ Department of Animal Science, Faculty of Agriculture, Shahid Bahonar University of Kerman, Kerman, Iran ${ }^{2}$ Department of Animal Science, Faculty of Agricultural Sciences and Engineering, University of Tehran, Karaj, Iran.

\begin{abstract}
Screening the fertile ewes from national herds to detect the major genes for prolificacy is an effective way to create the fertile flocks. Growth differentiation factor $(G D F) 9$ is a member of the transforming growth factor $\beta$ superfamily that is essential for folliculogenesis and female fertility. The aim of this study was to detect single nucleotide polymorphisms (SNPs) in exon 2 of GDF9 gene in Kermani sheep breed using PCR-SSCP. Genomic DNA was extracted from whole blood of collected samples using salting-out method. Whole exon 2 of GDF9 gene was amplified (634 bp and 647 bp fragments) using designed specific primers. The single stranded conformation polymorphism (SSCP) patterns of PCR products were studied using electrophoresis on acrylamide gel and silver-nitrate staining method. Finally, 4 banding patterns for the first primer pair and 4 banding patterns for the second primer pair were obtained. Also, indices of population genetic per SNP were calculated using Gen Alex 6.41 software. The sequencing results showed the presence of 3 mutations (SNP) (443, 477 and 721 positions) in the studied population.
\end{abstract}

Key words: fertility, GDF9 gene, Kermani sheep, PCR-SSCP, SNP.

\section{Introduction}

For decreasing the number of low-efficient ewes on pastures and preventing pastures demolition, animal breeding programs are necessary to identify effective candidate genes for the economical traits, especially genes with major effects affecting litter size in Iranian sheep breeds. Genetic variation in ovulation rate in sheep has been widely documented and the evidences show substantial differences among breeds and in a number of cases exceptional variations within breeds/strains (Bindon et al. 1996).
Growth differentiation factor (GDF) 9 is a member of the transforming growth factor $\beta$ superfamily that is secreted from oocytes during folliculogenesis (Aaltonen et al. 1999) and is essential for folliculogenesis and female fertility (Juengel et al. 2004). GDF9 deletion results in decreased granulosa cell proliferation, abnormal oocyte growth and failure of the follicles to develop past the primary stage (Dong et al. 1996). GDF9 also inhibits granulosa cell apoptosis and follicular atresia (Orisaka et al. 2006). Homozygous mutations of GDF9 detected in infertile sheep emphasize their essential role in this species (Aaltonen et al.

Correspondence to: M.R. Mohammadabadi, e-mail: mmohammadabadi@yahoo.ca and mrm@uk.ac.ir 
Table 1. Polymorphic sequence variations reported by Hanrahan et al. (2004) in GDF9 (growth differentiation factor 9 gene) within the Cambridge and F700-Belclare flocks.

\begin{tabular}{cccccc}
\hline Base change & Variant & $\begin{array}{c}\text { Coding } \\
\text { base (bp) }\end{array}$ & $\begin{array}{c}\text { Coding } \\
\text { residue (aa) }\end{array}$ & $\begin{array}{c}\text { Mature peptide } \\
\text { residue (aa) }\end{array}$ & $\begin{array}{c}\text { Amino acid } \\
\text { change }\end{array}$ \\
\hline G - A & G1 & 260 & 87 & & Arg (R)-His (H) \\
C - T & G2 & 471 & 157 & Unchanged Val (V) \\
G - A & G3 & 477 & 159 & & Unchanged Leu (L) \\
G - A & G4 & 721 & 241 & 8 & Glu (E)-Lys (K) \\
A - G & G5 & 978 & 326 & 14 & Unchanged Glu (E) \\
G - A & G6 & 994 & 332 & 53 & Val (V)-Ile (I) \\
G - A & G7 & 1111 & 371 & 77 & Ser (S)-Met (M) \\
C - T & G8 & 1184 & 395 & & She \\
\hline
\end{tabular}

1999). The gene spans about 2.5 kilo bases $(\mathrm{kb})$ and contains 2 exons separated by a single 1126-base pair (bp) intron. Exon 1 spans 397 bp and encodes for amino acids 1-134, while exon 2 spans 968 bp and encodes for amino acids 135-456 (Bodensteiner 1999). Bodensteiner et al. (2000) for the first time reported that the GDF9 mRNA expression was localized exclusively to oocytes of fetal sheep at day 135 of gestation. Sadighi et al. $(1998 ; 2002)$ mapped the GDF9 gene to ovine chromosome 5 .

$G D F 9$ was reported to be expressed exclusively in the ovary, specifically in the oocyte in mice (McGrath et al. 1995, Dube et al. 1998, Lan et al. 2003), rats (Vittet al. 2000), sheep (Bodensteiner et al. 1999, Juengel et al. 2002), cattle (Bodensteiner et al. 1999) and the human (Vitt et al. 2000). The combined results from sequence data and SSCP analysis of GDF9 by Hanrahan et al. (2004) revealed eight single nucleotide polymorphisms across the entire coding region (G1-G8; Table 1) and these differences correspond to one SNP in exon 1, one SNP in the intron, and five SNPs in exon 2. It is proven that exon 2 is more important than exon 1 and intron. Hence, we decided to study exon 2 in Kermani sheep.

Furthermore, a species without enough genetic diversity is thought to be unable to cope with changing environments or evolving competitors and parasites. In addition, the ability of a population to respond adaptively to environmental changes depends on its level of genetic variability or diversity (Askari et al. 2011).

Thus, genetic diversity in indigenous breeds is a major concern considering the necessity of preserving what may be a precious and irreplaceable richness, regarding new productive demands. Conservation should be based on a deep knowledge of the genetic resources of the specific breed. Therefore, it is important to try to genetically characterize indigenous breeds (Shojaei et al. 2010) and the applications of molecular genetics have many important advantages (Mousavizadeh et al. 2009). There are more than
50 million heads of sheep in Iran, of 27 breeds and ecotypes (Zamani et al. 2011). One of the most important breeds of Iranian sheep is Kermani sheep. This local breed lives in the south-eastern of Iran and is a fat-tail breed and well adapted to a wide range of harsh environmental conditions in Kerman province. The ability to adapt to different environmental circumstances is a desirable characteristic of this breed. This breed is one of the best Iranian wool sheep breeds which fleece is white and the wool is coarse and curly. The average weight for the rams is $48-50 \mathrm{~kg}$ and for the ewes, $45-48 \mathrm{~kg}$. Using molecular genetics methods similar to DNA markers is one of the best choices for faster and better accomplishment of animal breeding programs. Therefore, the aim of this study was to investigate the presence of polymorphism in GDF9 gene in the Kermani sheep breed.

\section{Materials and Methods}

\section{Experimental animals and DNA extraction}

The blood samples were randomly collected from Kermani sheep (102 animals) from both sexes and with different ages (Kerman, Iran), using vacuum tubes with $0.25 \%$ ethylene diamine tetra acetic acid (EDTA). The blood samples were transferred in dry ice to the laboratory and stored at $-20^{\circ} \mathrm{C}$ pending assays.

\section{DNA isolation}

Blood samples of the animals were used to extract genomic DNA using the salting out procedure described by Mohammad Abadi et al. (2009). The quality of DNA was checked by spectrophotometry taking ratio of optical density (OD) value at 260 and $280 \mathrm{~nm}$. Good quality DNA having OD ratio between 1.8 and 2 was used for further work. The poor quality DNA 
was re-extracted with the aforementioned method. Also, the quantity of extracted DNA was measured on $0.8 \%$ agarose gel.

\section{PCR primers and amplification}

The sheep GDF9 gene was amplified using the polymerase chain reaction (PCR) with designed specific primers (nucleotide sequence GenBank with accession number of AF078545).

The used PCR primers were as follows:

The first primer pair (Product length $=634 \mathrm{bp}$ ):

F:5'-GATTCCTTGATTTGACTTCCTGTT-3'; R: 5'-TGGCACTCTCCTGGTCTCTG-3' bp):

The second primer pair (Product length $=647$

F: 5'-TCACTGCTTTTGTATCTGAACGA-3'; R: 5'-CCAAAGGCATAGACAGGGGC-3'

These primers were used to amplify two fragments $634 \mathrm{bp}$ and $647 \mathrm{bp}$ of the first and second halves of the exon 2 for the sheep GDF9 gene, respectively.

The PCR reaction was performed in a $25 \mu \mathrm{L}$ reaction volume containing $2 \mu \mathrm{L}$ of genomic DNA (50 $\mathrm{ng} / \mu \mathrm{L}), 1 \mu \mathrm{L}$ of $\mathrm{MgCl} 2(3 \mathrm{mM}), 1 \mu \mathrm{L}$ of each forward and reverse primers (10 pmol each), $0.5 \mu \mathrm{L}$ of dNTPs $(500 \mu \mathrm{M}$ each), 0.3 unit of Taq DNA polymerase (Cinna Gene, Iran) and 10X PCR buffer. DNA amplifications were performed using thermo cycler (CLEMENS, Germany) programmed for a preliminary step of $5 \mathrm{~min}$ at $94^{\circ} \mathrm{C}$, followed by 33 cycles of 30 $\mathrm{s}$ at $94^{\circ} \mathrm{C}, 50 \mathrm{~s}$ at $62.5^{\circ} \mathrm{C}$ for the first primer pair and $63.6^{\circ} \mathrm{C}$ for the second primer pair and $50 \mathrm{~s}$ at $72^{\circ} \mathrm{C}$, with a final extension of $8 \mathrm{~min}$ at $72^{\circ} \mathrm{C}$. Amplification was verified by electrophoresis on $1 \%(\mathrm{w} / \mathrm{v})$ agarose gel in $1 \mathrm{x}$ TBE buffer $(2 \mathrm{mM}$ of EDTA, $90 \mathrm{mM}$ of Tris-Borate, $\mathrm{pH} 8.3$ ), using a 100bp ladder as a molecular weight marker for confirmation of the length of the PCR products. Gels were stained with ethidium bromide $(1 \mu \mathrm{g} / \mathrm{mL})$.

\section{Single stranded conformation polymorphism analysis}

The SSCP technique was used to allow the sequence variants to be detected from the migration shift in PCR amplified fragments of the gene (Orita et al. 1989a,b). For SSCP analysis, $6 \mu \mathrm{L}$ of each PCR product was mixed with $12 \mu \mathrm{L}$ of denaturing loading buffer (19 mL formamide, $0.98 \mathrm{gr} \mathrm{NaOH}(3 \% \mathrm{NaOH}$ solution), 0.01 gr xylene cyanol and $0.01 \mathrm{gr}$ bromophenol blue). The samples were denatured by heating at $95^{\circ} \mathrm{C}$ for $10 \mathrm{~min}$, then immediately chilled on ice and loaded onto $8 \%$ polyacrylamide gel
(37.5:1). Gels were run at $170-180 \mathrm{~V}$ for $7-8$ hours at $4^{\circ} \mathrm{C}$. The electrophoresis was carried out in a vertical unit in 1x TBE buffer (Tris $100 \mathrm{mM}$, boric acid $9 \mathrm{mM}$, EDTA $1 \mathrm{mM})$. The gels were stained with silver nitrate to observe the conformational patterns according to the method of Bassam et al (1991).

\section{Sequencing PCR products}

After revealing the single stranded conformation polymorphism (SSCP) patterns for this locus, from each of the ovine GDF9 variants identified by PCR-SSCP, one sample was sequenced (Mahan Gene, Iran).

\section{Statistical analysis}

The raw sequence data were edited using Bioedit 7.0 software. Multiple sequence alignments were performed with Bioedit 7.0 and DNAMAN software to identify single nucleotide polymorphisms (SNPs) in the exon 2 of the GDF9 gene in Kermani sheep. The nucleotide sequence of exon 2 was translated to amino acid sequence for each particular allelic variant. The BLAST algorithm was used to search the NCBI GenBank (http://www.ncbi.nlm.nih.gov/) databases for comparison of the ovine GDF9 sequences with homologous sequences of other animals to determine similarity percentage and detect the novel SNPs in the studied locus.

\section{Population genetic parameters}

Population genetic parameters including the allelic and genotypic frequencies, Hardy-Weinberg equilibrium, $\mathrm{Na}$ (number of different alleles), $\mathrm{Ne}$ (number of effective alleles $=1 /($ Sum pi^2)), I (Shannon's information index $=-1 * \operatorname{Sum}(\mathrm{pi} * \operatorname{Ln}(\mathrm{pi})))$, Ho ( observed heterozygosity $=$ number of Hets $/ \mathrm{N}), \mathrm{He}(\mathrm{ex}-$ pected heterozygosity $=1-\mathrm{Sum} \mathrm{pi}^{\wedge} 2$ ) and UHe (unbiased expected heterozygosity $=(2 \mathrm{~N} /(2 \mathrm{~N}-1)) * \mathrm{He})$ in the ovine GDF9 locus in the studied population were obtained using GenAlex6.41 software. We reported allelic frequency of the ovine GDF9 locus for two alleles of each single nucleotide polymorphism (SNP) and allelic sequences as well.

Also, haplotypes sequences forming each genotype for two loci were predicted using the $\mathrm{R}$ software.

The study protocol was approved by the Iranian ethics commission and analgesic and anesthetic procedures were not used. 


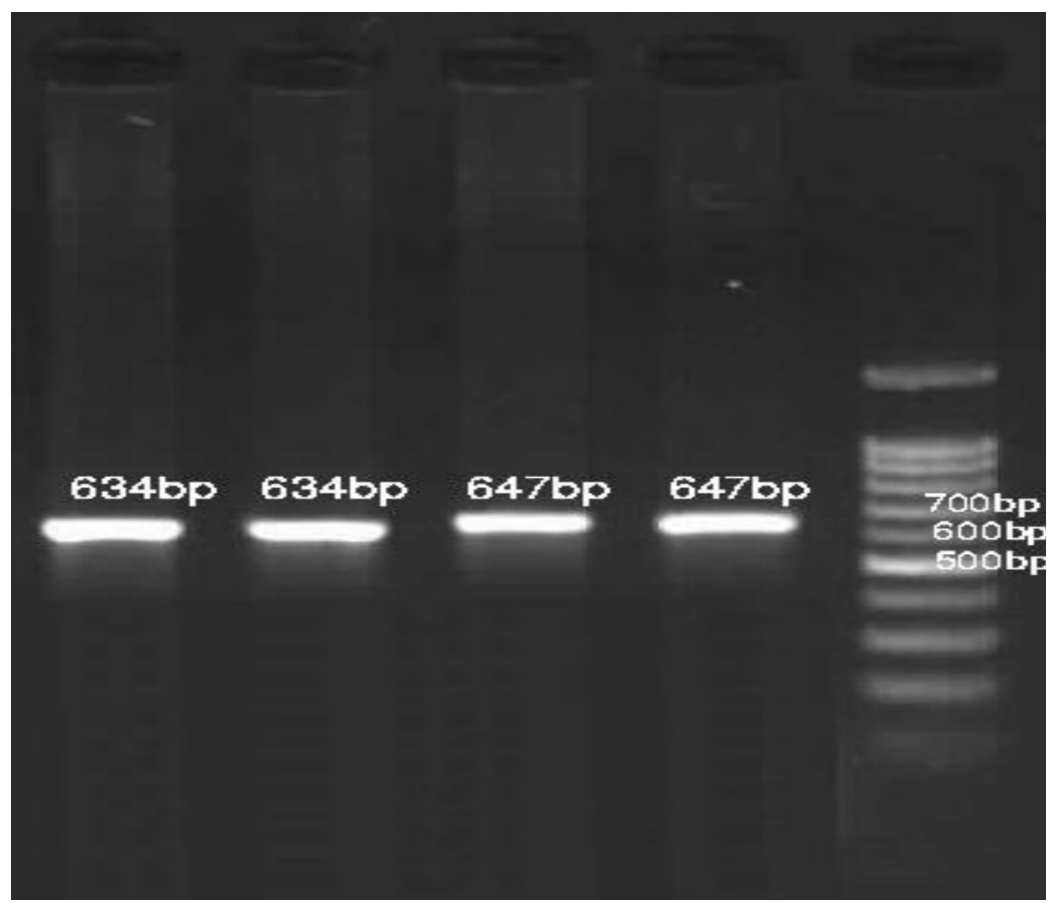

Fig. 1. Electrophoresis of PCR products on 1\% agarose gel for exon 2 of GDF9 gene in Kermani sheep.

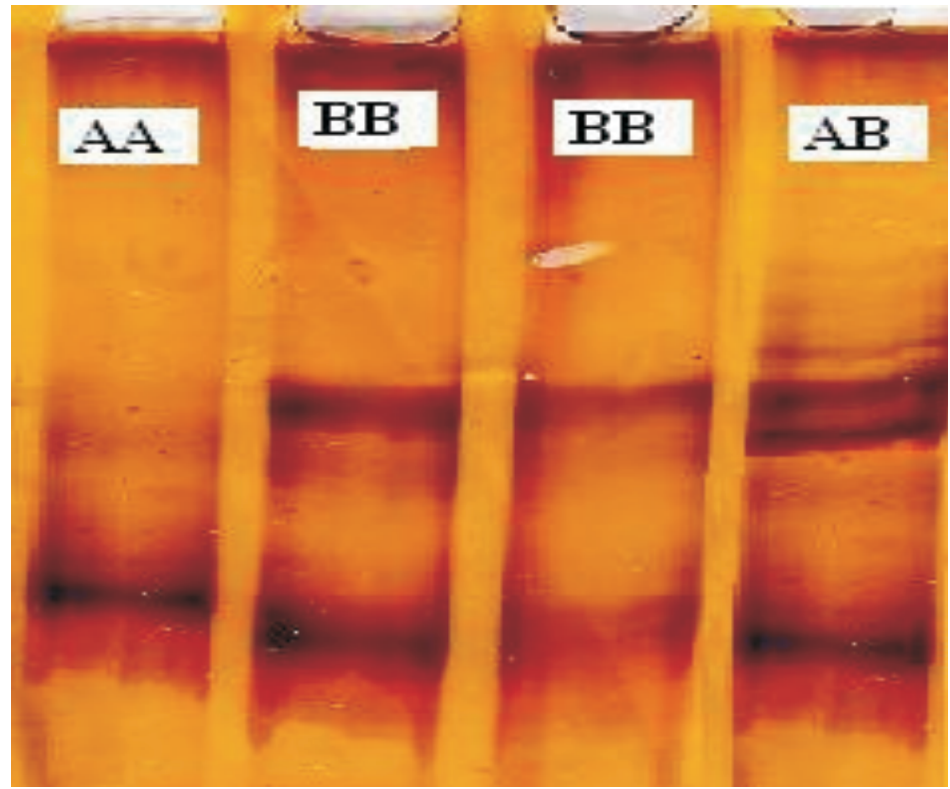

Fig. 2. PCR-SSCP patterns of $634 \mathrm{bp}$ fragment of the first half of the exon 2 in the Kermani sheep GDF9 gene.

\section{Results}

As expected, PCR amplification of the ovine GDF9 gene for Kermani sheep gave uniform fragments of $634 \mathrm{bp}$ and $647 \mathrm{bp}$ by running on $1 \%$ agarose gel (Fig. 1) and the amplified fragments sizes were consistent with the expected size and subsequently sequencing of the ovine GDF9 amplicons confirmed them to be either $634 \mathrm{bp}$ or $647 \mathrm{bp}$ in size. PCR prod- ucts were also assessed with M100 size marker (Cinna Gene, Iran).

The SSCP analysis revealed three unique banding patterns for the first half of the exon and four unique banding patterns for the second half of the exon representing different allelic variants (Fig. 2, 3). These seven banding patterns constituted different genotypes in the Kermani sheep breed (Fig. 2, 3). The individual animals with one or two different SSCP 


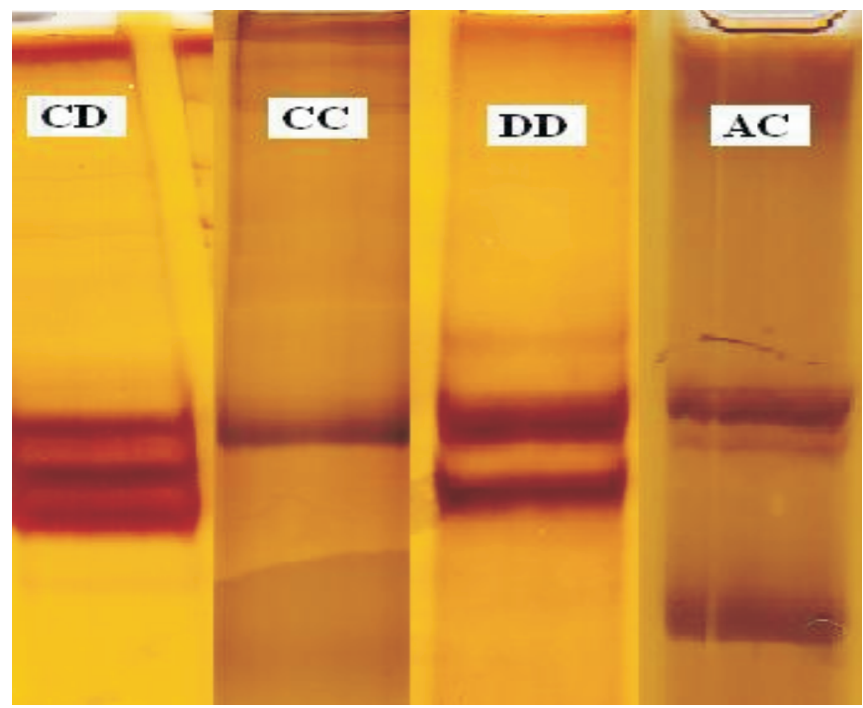

Fig. 3. PCR-SSCP patterns of $647 \mathrm{bp}$ fragment of the second half of the exon 2 in the Kermani sheep GDF9 gene.

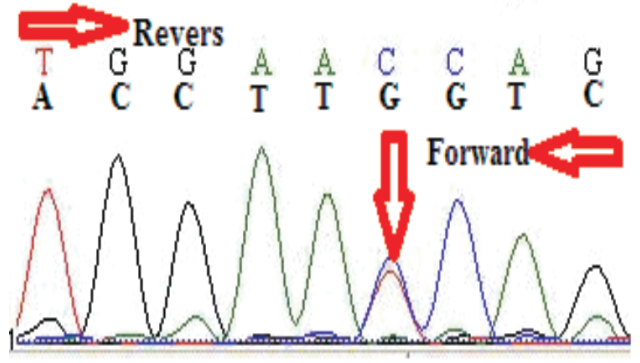

N 994 G\&A

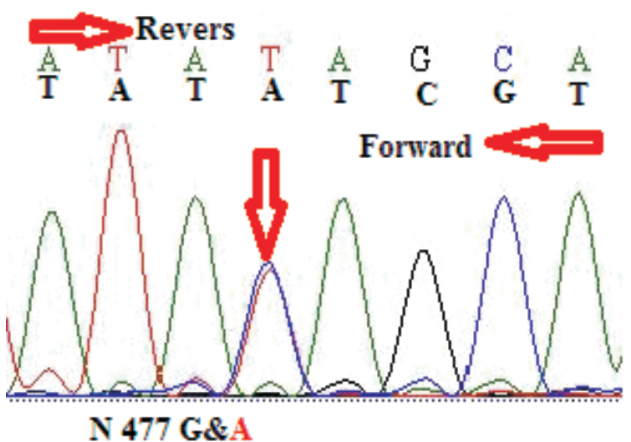

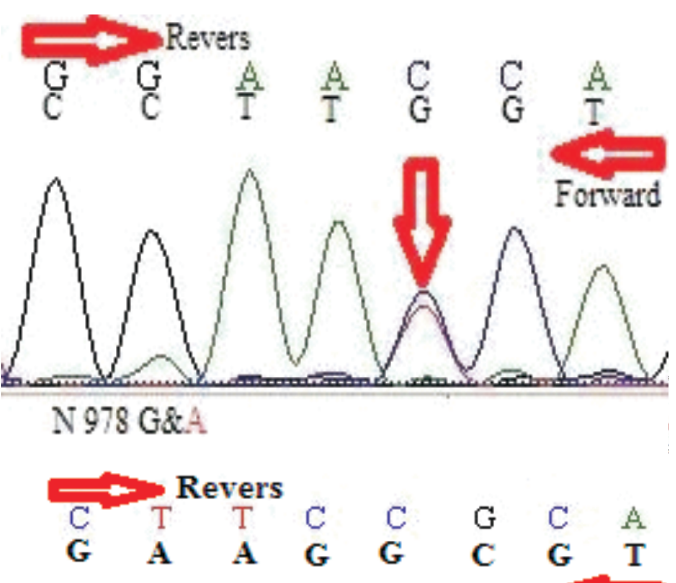
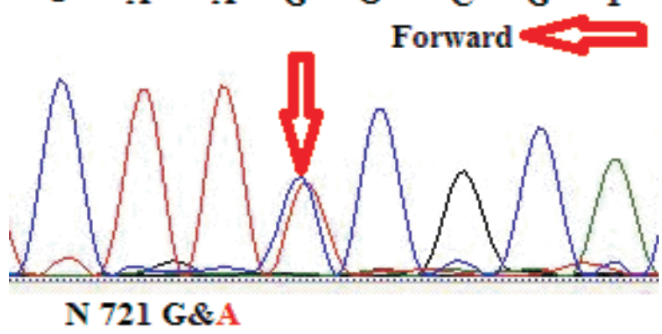

Fig. 4. Partial sequence comparison of the altered bases of GDF9 in Kermani sheep.

patterns were observed, which are the representative of the homozygous and heterozygous genotypes at the GDF9 locus, respectively.

Based on our sequence analysis, the SNPs identified for the first and second halves of the exon 2 constituted three and four different sequences, respectively, which confirmed the results of the SSCP analysis. This insured that these sequences represented genuine ovine sequences rather than being the result of PCR and/or sequencing errors. All consensus sequences showed 98-99\%, 94-98\%, 92-93\% and $82-83 \%$ similarity to the published ovine, caprine, bovine and porcine GDF9 locus sequences, respectively. Two SNPs detected in exon 2 were non-synonymous substitutions which would result in $721 \mathrm{Gln} / \mathrm{Lys}$ and $994 \mathrm{Val} / \mathrm{Ilu}$. Also, two SNPs detected were synonymous substitutions which would result in 477 for Leu and 978 for Glu substitutions in domain L of the mature GDF9 protein.

In the studied population, three different geno- 
Table 2. Detected genotypes in the exon 2 of GDF9 gene in Kermani sheep population.

\begin{tabular}{clll}
\hline & & SNP Position in sequence of GDF9 gene \\
\hline frequency & 721 & 477 & number of genotypes for the first half of the exon 2 \\
0.187 & GG & GG & 1 \\
0.333 & GG & AA & 2 \\
0.480 & GA & GA & 3 \\
frequency & 994 & 978 & number of genotypes for the second half of the exon 2 \\
0.137 & GG & AA & 1 \\
0.411 & AA & GG & 2 \\
0.265 & GA & GA & 3 \\
0.187 & GA & AA & 4 \\
\hline
\end{tabular}

Table 3. Detected haplotypes in the exon 2 of GDF9 gene in Kermani sheep population.

\begin{tabular}{cccc}
\hline & \multicolumn{3}{c}{ SNP Position in sequence GDF9 gene } \\
\hline frequency & 721 & 477 & number of haplotypes for the first half of the exon 2 \\
0.186 & G & G & 1 \\
0.574 & G & A & 2 \\
0.240 & A & G & 3 \\
frequency & 994 & 978 & number of haplotypes for the second half of the exon 2 \\
0.362 & G & A & 1 \\
0.338 & A & G & 2 \\
0.300 & A & A & 3 \\
\hline
\end{tabular}

Table 4. SNPs detected in the ovine GDF9 gene, and their allelic and genotypic frequencies for the studied population.

\begin{tabular}{|c|c|c|c|c|c|c|}
\hline \multirow{2}{*}{$\frac{\mathrm{P} \text {-value }}{0.856}$} & \multicolumn{3}{|c|}{ genotypic frequency } & \multicolumn{2}{|c|}{ allelic Frequency } & \multirow{2}{*}{$\frac{\text { SNP position }}{477^{\mathrm{ns}}}$} \\
\hline & $\underline{\mathbf{A A}}$ & GA & GG & A & $\mathrm{G}$ & \\
\hline & $0 . \overline{332}$ & 0.482 & 0.186 & 0.574 & 0.436 & \\
\hline \multirow[t]{2}{*}{0.001} & AA & GA & GG & A & $\mathrm{G}$ & $721^{* *}$ \\
\hline & 0.000 & 0.481 & 0.519 & 0.24 & 0.76 & \\
\hline \multirow[t]{2}{*}{0.000} & GA & $\mathrm{AG}$ & $\mathrm{AA}$ & $\mathrm{G}$ & A & $978^{* * *}$ \\
\hline & 0.412 & 0.265 & 0.323 & 0.544 & 0.456 & \\
\hline \multirow[t]{2}{*}{0.804} & $\underline{\mathbf{A} A}$ & GA & GG & A & $\mathrm{G}$ & $994^{\mathrm{ns}}$ \\
\hline & 0.411 & 0.450 & 0.137 & 0.637 & 0.363 & \\
\hline
\end{tabular}

ns: not significant (population is in Hardy-Weinberg Equilibrium); ** and *** significant in 0.001 and 0.0001 respectively (population is not in Hardy-Weinberg equilibrium); wild allele (correspond to haplotype 1) is underlined and bolded.

Table 5. Population genetic parameters in each of the four SNPs identified in the ovine GDF9 locus in the Kermani sheep population.

\begin{tabular}{ccccccc}
\hline UHe & He & Ho & I & Ne & Na & SNP Position \\
\hline 0.492 & 0.489 & 0.480 & 0.682 & 1.958 & 2.000 & 477 \\
0.367 & 0.365 & 0.480 & 0.551 & 1.575 & 2.000 & 721 \\
0.499 & 0.496 & 0.265 & 0.689 & 1.985 & 2.000 & 978 \\
0.465 & 0.462 & 0.451 & 0.655 & 1.860 & 2.000 & 994 \\
\hline
\end{tabular}

types and three haplotypes were observed for the first half of the exon 2 and four different genotypes and three haplotypes were observed for the second half of the exon 2. Frequencies of the detected genotypes and haplotypes in the studied population are provided in Table 2 and 3. In total, in this population, genotype
3 in the first half of the exon 2 and genotype 2 in the second half of the exon 2 were most common with a frequency of 0.480 and 0.411 , respectively.

For the four identified SNPs, the number of genotyped individuals and the allele frequencies in the studied sheep breed are presented in Table 4 . The 
SNP g.721G $>$ A located in the first half of the exon 2 displayed the least variability, with a value of the least frequent allele below 0.24 in studied population. Also, homozygosity of mutant allele for this SNP was not detected in this population.

In total, frequency of the least frequent alleles in the first and second halves of the exon 2 ranged from 0.24 (SNP g.721G $>$ A) to 0.36 (SNP g.994 G>A) in this population.

Values for the observed number of alleles $(\mathrm{Na})$, the effective number of alleles $(\mathrm{Ne})$, the Shannon's index (I), observed heterozygosity (Ho), expected heterozygosity $(\mathrm{He})$ and unbiased expected heterozygosity (UHe) of each of the four SNPs identified in the ovine GDF9 locus for the studied sheep population are provided in Table 5 .

\section{Discussion}

In this research, we analyzed the polymorphic variations of the gene coding for the growth differentiation factor (GDF) 9, a member of the transforming growth factor $\beta$ superfamily that is essential for folliculogenesis and female fertility, in Kermani sheep breed. Thus, the complete exon 2 of this gene was analyzed for 102 animals using designed specific primers, PCR-SSCP method and DNA sequencing.

It should be noted that Hanrahan et al. (2004) studied some parts of exon 2 of GDF9 gene using four specific primers pairs while we amplified total exon 2 of GDF9 gene using two pairs of designed specific primers covering total exon 2 of GDF9 gene leading to decreased expenses and experiment time. Observation of only one band on agarose gel indicated that the designed primers were specific and there was not DNA sequence similarity at other situations, which could be directly analyzed by SSCP.ą

Using the SSCP technique and sequence analysis of the exon 2 together four SNPs were observed. Two SNPs were located in the first half of the exon $2(\mathrm{~A} 477 \rightarrow \mathrm{G}$ and $\mathrm{A} 721 \rightarrow \mathrm{G})$ and two SNPs were located in the second half of the exon 2 (G978 $\rightarrow$ A and $\mathrm{A} 994 \rightarrow \mathrm{G}$ ) for the $G D F 9$ gene. After the BLAST search of amplified sequences of exon 2 of GDF9 gene in NCBI to get open reading frame for start properly translation to protein sequence, we got from $+1(+1$ means that translation to protein sequence started from the first nucleotide of the first codon, +2 means that translation to protein sequence started from the second nucleotide of the first codon and +3 means that translation to protein sequence started from the third nucleotide of the first codon) for both amplified sequences. Two of the four polymorphisms were nucleotide changes that do not result in an alter- ed amino acid (G3 at nucleotide 477, and G5 at nucleotide position 978). The two remaining nucleotide changes, i.e. G4 and G6, gave rise to amino acid changes (conservative changes) (Table 1). Both G6, valine to isoleucine change at amino acid residue 332 of the unprocessed protein (residue 14 of the mature coding region), and $\mathrm{G} 7$, valine to methionine at residue 371 of the unprocessed protein (residue 53 of the mature coding region), substitute nonpolar groups with nonpolar groups. The remaining two changes result in non-conservative substitutions. G4, glutamic acid to lysine change at amino acid residue 241 of the unprocessed protein, replaces an acidic group with a basic group, but this occurs at a position before the furin processing site and it is unlikely to affect the mature active coding region.

Hanrahan et al. (2004) discovered eight variants (G1 to G8) of GDF9 gene in Cambridge and Belclare sheep breeds using PCR-SSCP and sequencing. However, G8 variant caused serine to phenylalanine substitution at residue 395 which replaced an uncharged polar amino acid with a nonpolar one at residue 77 of the mature coding region and may change the function of GDF9 in sheep (Hanrahan et al. 2004). Nikol et al. (2009) discovered 4 variants (G3, G4, G5 and G6) of GDF9 gene in Icelandic Thoka sheep that is in agreement with the result of the present study. Guan et al. (2005) detected the G8 mutation of GDF9 gene in Hu sheep using PCR-RFLP and the mutation rate was rare $(0.645 \%)$. They found two SNPs (T558C and T692C (Leu231Thr)) in the exon 2 of GDF9 in small tail Han, Tong, Tan and Oula sheep using PCR-SSCP (Guan et al. 2005). Recently, two variants of sheep GDF9 have been reported, FecGSI (T1034G mutation of CDS region resulting in Phe27Cys change of mature protein) in Brazilian Santa Ines sheep (Melo et al. 2008) and FecTT (A1279C mutation of CDS region resulting in Ser109Arg of mature protein) in Icelandic Thoka sheep (Nikol et al. 2009). Chang et al. (2009) identified G2 mutation of GDF9 gene in small tail Han, white Suffolk, Texel and Tibetan sheep using PCR-SSCP. They detected G4 mutation of GDF9 in small tail Han, Poll Dorset, Suffolk, German Mutton Merino and Chinese Merino (Xinjiang type) (including prolific strain, meat strain and large frame strain) by PCR-SSCP. In the present study, we did not find any genetic variations for $\mathrm{G} 2(\mathrm{G} 471 \rightarrow \mathrm{C}), \mathrm{G} 7$ $(\mathrm{A} 1111 \rightarrow \mathrm{G})$ and $\mathrm{G} 8(\mathrm{~T} 1184 \rightarrow \mathrm{C})$ within the GDF9 gene using PCR-SSCP among the studied animals of the Kermani breed. Until now among Iranian sheep breeds, G8 mutation of GDF9 was not detected. Our samples were randomly taken from this flock and one would expect to find all possible genotypes of GDF9 if it really segregates in this breed. Moreover, G8 mutation of $G D F 9$ was not detected in small tail $\mathrm{Han}, \mathrm{Hu}$, 
Dorset, Texel and German Mutton Merino sheep (Chu et al. 2005), Suffolk, Dorset, Charollais, Romney Hills and Chinese Merino sheep (Guan et al. 2007), Cele and Duolang sheep in China (Bai et al. 2005), Shal sheep in Iran (Ghaffari et al. 2009), Tan sheep in China (Sun et al. 2009), Barbarine, Queue Fine de L'Ouest, Noire dehibar, Sicilo-Sarde, D'man sheep in the North Africa (Vacca et al. 2010) that is in agreement with the present study. Eghbal Saied et al. (2012) discovered that the arisen G4 mutation in Iranian Afshari sheep has led to the maximum ovulation rate compared with other breeds that they studied. Therefore, this mutation may be responsible for the increased ovulation rate in some sheep breeds.

Observed heterozygosity $\left(\mathrm{H}_{\mathrm{O}}\right)$ in each of the three SNPs 477, 721 and 994 was $0.480,0.480$ and 0.451, respectively. SNP G978 $\rightarrow$ A displayed the lowest average heterozygosity across the studied sheep breed $(0.265)$. These results showed that genetic variation for GDF9 gene in the studied sheep breed is moderate to high.

Findings demonstrated that the G8 mutation changes an uncharged polar serine residue (residue 77 of mature GDF9) to a nonpolar phenylalanine in a region of the molecule that is likely to be involved in binding to the type I receptor. Therefore, this mutation could affect the ability of the ligand to bind to a receptor. However, this change also occurs only three residues away from a conserved histidine of the mature GDF9 peptide. GDF9 lacks the interchain disulphide bond that forms a covalent link between monomers of the biologically active dimer in most other members of the TGFb superfamily. Thus, it is possible that in GDF9, the hydrogen bonds between monomers are even more critical for maintaining dimer stability and the G8 mutation could affect biological activity by disrupting dimerization.

The high level of genetic variability observed in the coding region of the ovine GDF9 gene in this study suggests that this region of the GDF9 gene probably affects folliculogenesis and female fertility in sheep; hence further association studies using appropriate populations are needed to identify genetic variants that can be used as markers related to fertility.

\section{Conclusion}

The results of our study emphasized that in this selected population of Kermani sheep, there are G3 $(\mathrm{A} 477 \rightarrow \mathrm{G}), \mathrm{G} 4(\mathrm{~A} 721 \rightarrow \mathrm{G}), \mathrm{G} 5(\mathrm{G} 978 \rightarrow \mathrm{A})$ and G6 $(\mathrm{A} 994 \rightarrow \mathrm{G})$ mutations in the ovine GDF9 gene. G2 $(\mathrm{G} 471 \rightarrow \mathrm{C}), \mathrm{G} 7(\mathrm{~A} 1111 \rightarrow \mathrm{G})$ and G8 $(\mathrm{T} 1184 \rightarrow \mathrm{C}) \mathrm{mu}-$ tations are completely absent and they are not asso- ciated with litter size in Kermani sheep. Reproductive activity is a multifunctional process and numerous genes, proteins, growth factors and hormones are involved in this activity. The SNPs discovered in this study can be used for the ovine SNP chip design project in future. The discovered alleles and genotypes can also be used as markers in marker-assisted selection of sheep for economic traits in future.

\section{References}

Aaltonen J, Laitinen MP, Vuojolainen K, Jaatinen R, Horelli-Kuitunen N, Seppa L, Louhio H, Tuuri T, Sjoberg J, Butzow R, Hovata O, Dale L, Ritvos O (1999) Human growth differentiation factor 9 (GDF9) and its novel homolog GDF9-B are expressed in oocytes during early folliculogenesis. J Clin Endocrinol Metab 84: 2744-2750.

Askari N, Mohammadabadi M, Baghizadeh A (2011) ISSR markers for assessing DNA polymorphism and genetic characterization of cattle, goat and sheep populations. Iranian J Biotech 9: 222-229.

Bai J, Shi HC, Liu MJ, Li F (2007) Study on GDF9 and $B M P 15$ as candidate genes for fecundity in Cele Black sheep and Duolang sheep. Grass-Feed Livestock 2: 1-4.

Bassam BJ, Caetano-Anolles G, Gresshoff PM (1991) Fast and sensitive silver staining of DNA in polyacrylamide gels. Anal Biochem 196: 80-83.

Bodensteiner KJ, Clay CM, Moeller CL, Sawyer HR (1999) Molecular cloning of the ovine growth/differentiation factor-9 gene and expression of growth/differentiation factor-9 in ovine and bovine ovaries. Biol Reprod 60: 381-386.

Bodensteiner KJ, McNatty KP, Clay CM, Moeller CL, Sawyer HR (2000) Expression of growth and differentiation factor-9 in the ovaries of fetal sheep homozygous or heterozygous for the inverdale prolificacy gene (FecXI). Biol Reprod 62: 1479-1485.

Bodin L, Elsen JM, Poivey JP, San Cristobal-Gaudy M, Belloc JP, Eychenne F (1998) Hyper-prolificacy in the French Lacaune sheep breed; a possible major gene. In: Proceedings of the Sixth World Congress on Genetics Applied to Livestock Production, Armidale, Australia, 27, pp. 1-14.

Chang JT, Luo YZ, Hu J (2009) Polymorphism of GDF9 as a candidate gene for fecundity in sheep. J Gansu Agric Univ 44: 30-33.

Chen Y, Luo QJ, Zhang YJ, Zhu WY, Yang JQ, Li DZ, Yang FY (2009) Relationships between genetic polymorphisms of BMP15 and GDF9 gene and litter size of sheep. J Xinjiang Agric Univ 32: 10-17.

Chu MX, Sang LH, Wang JY, Fang L, Ye SC (2005) Study on $B M P I 5$ and $G D F 9$ as candidate genes for prolificacy of Small Tail Han sheep. Acta Genetica Sinica (Yi Chuan Xue Bao) 32: 38-45.

Dong J, Albertini DF, Nishimori K, Kumar TR, Lu N, Matzuk MM (1996) Growth differentiation factor-9 is required during early ovarian foliculogenesis. Nature 383: 531-535.

Dube JL, Wang P, Elvin J, Lyons KM, Celeste AJ, Matzuk MM (1998) The bone morphogenetic protein 15 gene is 
X-linked and expressed in oocytes. Mol Endocrinol 12: 1809-1817.

Eghbalsaied S, Ghaedi K, Shahmoradi S, Pirestani A, Amini H, Saidi T, Nicol L, McNeilly A (2012) Presence of SNPs in GDF9 mRNA of Iranian Afshari sheep. Int J Fertil Steril 5: 225-230.

Gao LX (2007) Polymorphisms of TGF-b1 and GDF9 genes and their relationships with prolificacy in Small Tail Han sheep. Thesis for M.S., Chinese Academy of Agricultural Sciences, pp 32-36.

Ghaffari M, Nejati-Javaremi A, Rahimi-Mianji G (2009) Lack of polymorphism in the oocyte derived growth factor $(G D F 9)$ gene in the Shal breed of sheep. S Afr J Anim Sci 39: 355-360

Guan F, Ai JT, Pang XS, Liu SR, Shi GQ, Yang LG (2005) Detection of the polymorphisms of GDF9 and BMP15 genes in sheep. Life Sci Res 9: 184-188.

Hanrahan, JP, Gregan SM, Mulsant P, Mullen M, Davis GH, Powell R, Galloway SM (2004) Mutations in the genes for oocyte-derived growth factors GDF9 and BMP15 are associated with both increased ovulation rate and sterility in Cambridge and Belclare sheep (Ovis aries). Biol Reprod 70: 900-909.

Juengel JL, Bodensteiner KJ, Heath DA, Hudson NL, Moeller CL, Smith P, Galloway SM, Davis GH, Sawyer HR, McNatty KP (2004) Physiology of GDF9 and BMP15 signalling molecules. Anim Reprod Sci 82-83: 447-460.

Juengel JL, Hudson NL, Heath DA, Smith P, Reader KL, Lawrence SB, O;Connell AR, Laitinen MP, Cranfield M, Groome NP, Ritvos O, McNatty KP (2002) Growth differentiation factor 9 and bone morphogenetic protein 15 are essential for ovarian follicular development in sheep. Biol Reprod 67: 1777-1789.

Lan ZJ, Gu P, Xu X, Jackson KJ, DeMayo FJ, O'Malley BW, Cooney AJ (2003) GCNF-dependent repression of BMP-15 and GDF-9 mediates gamete regulation of female fertility. EMBO J 22: 4070-4081.

McGrath SA, Esquela AF, Lee SJ (1995) Oocyte-specific expression of growth/differentiation factor-9. Mol Endocrinol 9: 131-136.

Melo EO, Silva BD, Castro EA, Silva TA, Paiva SR, Sartori R, Franco MM, Souza CJ, Neves JP (2008) A novel mutation in the growth and differentiation factor 9 (GDF9) gene is associated, in homozygosis, with increased ovulation rate in Santa Ines sheep. Biol Reprod 78 (Suppl 1): 141.

Mohammad Abadi MR, Askari N, Baghizadeh A, Esmailizadeh AK (2009) A directed search around caprine candidate loci provided evidence for microsatellites linkage to growth and cashmere yield in Rayini goats. Small Ruminant Res 81: 146-151.
Mousavizadeh A, Mohammad Abadi MR, Torabi A, Nassiry MR, Ghiasi H, Esmailizadeh AK (2009) Genetic polymorphism at the growth hormone locus in Iranian Talli goats by polymerase chain reaction-single strand conformation polymorphism (PCR-SSCP). Iranian J Biotech 7: 51-53.

Nicol L, Bishop SC, Pong-Wong R, Bendixen C, Holm LE, Rhind SM, McNeilly AS (2009) Homozygosity for a single base-pair mutation in the oocyte-specific GDF9 gene results in sterility in Thoka sheep. Reproduction 138: 921-933.

Orisaka M, Orisaka S, Jiang JY, Craig J, Wang Y, Kotsuji F, Tsang BK (2006) Growth differentiation factor 9 is antiapoptotic during follicular development from preantral to early antral stage. Mol Endocrinol 20: 2456-2468.

Orita M, Iwahana H, Kanazawa H, Hayashi K, Sekiya $\mathrm{T}$ (1989a) Detection of polymorphisms of human DNA by gel electrophoresis as single-strand conformation polymorphisms. Proc Natl Acad Sci USA 86: 2766-2770.

Orita M, Suzuki Y, Sekiya T, Hayashi K (1989b) Rapid and sensitive detection of point mutations and DNA polymorphisms using the polymerase chain reaction. Genomics 5: 874-879.

Sadighi M, Bodensteiner KJ, Beattie AE, Galloway SM (2002) Genetic mapping of ovine growth differentiation factor $9(G D F 9)$ to sheep chromosome 5. Anim Genet 33: 244-245.

Sadighi M, Montgomery W, Bodensteiner KJ, Galloway SM (1998) The growth differentiation factor 9 maps to sheep chromosome 5. Anim Genet 29 (Suppl 1): 36.

Shojaei M, Mohammad Abadi M, Asadi Fozi M, Dayani O, Khezri A, Akhondi M (2010) Association of growth trait and Leptin gene polymorphism in Kermani sheep. J Cell Mol Res 2: 67-73.

Sun H, Tian X, Wang Y (2009) BMPR-IB, BMP15 and GDF9 as candidate genes for prolific trait in Tan sheep. Acta Agricul Boreali-Occident Sin 18: 17-21.

Vacca GM, Dhaouadi A, Rekik M, Carcangiu V, Pazzola M, Dettori ML (2010) Prolificacy genotypes at BMPR1B, $B M P 15$ and GDF9 genes in North African sheep breeds. Small Ruminant Res 88: 67-71

Vitt UA, McGee EA, Hayashi M, Hsueh AJ (2000) In vivo treatment with $G D F-9$ stimulates primordial and primary follicle progression and theca cell marker CYP17 in ovaries of immature rats. Endocrinology 141: 3814-3820.

Zamani P, Akhondi M, Mohammadabadi MR, Saki AA, Ershadi A, Banabazi MH, Abdolmohammadi AR (2011) Genetic variation of Mehraban sheep using two intersimple sequence repeat (ISSR) markers. Afr J Biotechnol 10: 1812-1817. 